\title{
The Politics of Development and Participatory Planning. From Top Down to Top Down
}

\author{
Victor Lord Owusu ${ }^{1}$ \\ ${ }^{1}$ Department of Political Science, Carleton University, Ottawa, Canada \\ Correspondence: Victor Lord Owusu, Department of Political Science, Carleton University, 1125 Colonel By Dr, \\ Ottawa, ON K1S 5B6, Canada. Tel: 1-613-619-6233. Emails: owusulord@ymail.com; lordowusu24@yahoo.ca
}

Received: November 18, 2014

Accepted: November 18, 2015 Online Published: January 26, 2016

doi:10.5539/jsd.v9n1p202

URL: http://dx.doi.org/10.5539/jsd.v9n1p202

\begin{abstract}
This paper measures the level of participation in Ghana's four most recent development policy and planning documents, from the Vision 2020 to the Ghana Shared Growth and Development Agenda. Using Systematic Review and a developed modified version of Arnstein's Ladder of Citizen Participation, the paper concludes that development planning in Ghana is top down and non participatory. The paper further uncovered that civilian and military governments before and after independence in 1957 adopted the top down approach and planned from the centre with no traces of citizens' participation in the planning processes. It was further determined that this top down and non participatory mode of planning is deeply enshrined in Ghana's current and past development planning culture and history, a legacy bequeathed to colonies by colonialists.
\end{abstract}

Keywords: bottom up, control from the top, citizen participation, development planning, development plans, participation, top down

\section{Introduction}

The roots of this paper and my unending interest in institutional documents are in my doctoral thesis that focus was on the making of policies and plans. The $20^{\text {th }}$ century eventually witnessed a big push globally towards the involvement of citizens in decisions that affect them at both the national and local levels. The antecedent of this big push dates back to the 1950s. Burke states that 'prior to the 1950s community planning was the exclusive domain of a single organization-the city planning agency or department' $(1979,11)$. He continues: 'human services or social planning was virtually nonexistent-at least at the magnitude we know today' $(1979,12)$. Burke outlines several events that have shaped the outlook of planning since the 1950s. He argues that 'multiple planning centres, citizen participation, and changed decision environment have markedly affected the scope, practice, and objectives of planning...'(1979, 12). And to Burke list have been added the end of colonialism, self-government, independence and democratic governance.

The end of colonialism, the beginning of self-government and the emergence of democratic elections led to the awakening of the principle of citizen participation. Also referred to in this paper as the 'bottom up' approach, this 'new model' of citizen participation was quickly adopted by development planners in developing countries. This approach was a complete opposite to the 'top down' model; an approach practiced under Ghana's British colonial masters, institutionalized by successive governments in the country before and after independence and formalized as a policy option during years of military rule.

Before proceeding, the following clarifications are provided. Development planning covers the processes and procedures of making a plan, whether local or national. It involves the institutions, instructions and guidelines used in the process. The output of a development planning process is a development plan - a document that outlines what a planning body (local or central) is setting up to accomplish within a specified time period in both physical and non-physical terms. A 'bottom up' approach centres around participation of the people in development planning. On the contrary, a plan or/and planning process dictated in various form by central authorities, be it the presidency, an ad hoc or formal national planning body and/or foreign institutions and/or governments falls under the definition of 'top down'. Dye refers to policy makers at the top as 'the national elite' $(2001,1)$. This is a broad and diverse group of individuals and institutions that inform, influence and/or dictate national development policies. Specifically, the national elite are those 'who formulate, manage, and direct the policies and activities of government...' (Dye 2001, 2). 
Referring to the 'top down' approach as 'control from the top', Friedmann (1987) traces the contemporary intellectual birth of this model of planning to the destruction and confusion of the First World War. He argues: 'the war had speeded up a change in public opinion that made it seem less outrageous than before that government should regulate business for a public purpose' $(1987,89)$. The actual materialisation and maturity of this intellectual birth did not occur for almost forty years, just around the time that Ghana and many colonists were becoming independent. Friedmann attributed this change in societal perception of state involvement in national development planning to Herbert Hoover (former Commerce Secretary and President of the United States) who argued for an 'associative state'- that is, government managing, speeding up and guiding the 'development planning process' $(1987,90)$. Although the initial debate about 'control from the top' was not planning specific, it was quickly adopted in various form by the emerging planning profession.

The American experience with control from the top was strengthened during the presidency of Roosevelt. He set up the National Planning Board, similar to Ghana's National Development Planning Commission (NDPC). To the board, wise planning was 'based on control of certain strategic points in a working system' (Friedmann 1987, 93). It involved a continuous reorganization as situation changes from time to time. Herein lies a clear testament of control from the top as practiced in the United States. As will be discussed later, Ghana's NDPC through various Acts of parliament continuously reorganizes the planning environment in the country. Control from the top in Western Europe followed a similar pattern-that is, emerging from the ruins of economic hardship, confusion and war. This time, the Second World War. Notable is the French Planning Commissariat. Masse states that the French Commissariat General du Plan and the idea of 'planification' were direct consequences of the war and not theory. He states: 'one cannot help being struck by the fact that in France practical planning preceded the theory by a long time...' $(1962,1)$.

The motivations for an ongoing appetite for national development planning from the top in Ghana are similar to the United States and France. Although now considered a stable democracy, Ghana have at varying stages and levels since independence in 1957 experienced periods of commodity shortages and war like confusion emanating from unstable economic indicators and regular military coups and counter coups. The country's economy, notably its currency (the Cedi) behaves like a restless pendulum from time to time. The very steep depreciation of the Cedi for example in 2012 and the continuous debate and controversies surrounding the rate and extent of depreciation that it created was nothing less than total confusion.

Arguments presented in this paper are structured in the following manner. After a discussion on the antecedents of participatory planning in the United States, Europe and Ghana and a clarification of key concepts in section one, the analysis moves on to the theoretical and methodological basis of the paper. Section three focuses on the history and culture of planning from the top in Ghana. The data is analysed and reviewed in section four and section five concludes the paper with several recommendations.

\section{Theoretical Underpinning}

Citizen participation at all levels of the planning process is today synonymous with contemporary planning practice. Burke emphatically states that 'it is axiomatic to conclude that planning is participatory' $(1979,65)$. To talk about the practice of planning without a mention of citizen participation is uncharacteristic of the planning profession and planning practice. Randolph agrees and argues that in planning, 'the rationale for public participation is both philosophical and pragmatic...'(2012, 43). Acceptability and success of implementation are gained largely through citizen participation. Arnstein (1969) Ladder of Citizen Participation places this paper within a suitable analytic frame.

Arnstein refers to citizen participation as a categorical term for 'citizen power' $(1969,216)$. She states that citizen participation is the redistribution of power that enables the have-nots to be deliberately included in the economic and political processes. That participation allows the have-nots to join in determining how information is shared, goals and policies are set and programmes operate. She concludes by referring to citizen participation as the means by which the have-nots can induce significantly social reform and ultimately share in the wealth of their country $(1969,216)$. A developed modified version of Arnstein's ladder with its eight stages of participation and non-participation to be used analytically in this paper is reproduced in figure 1 below. 


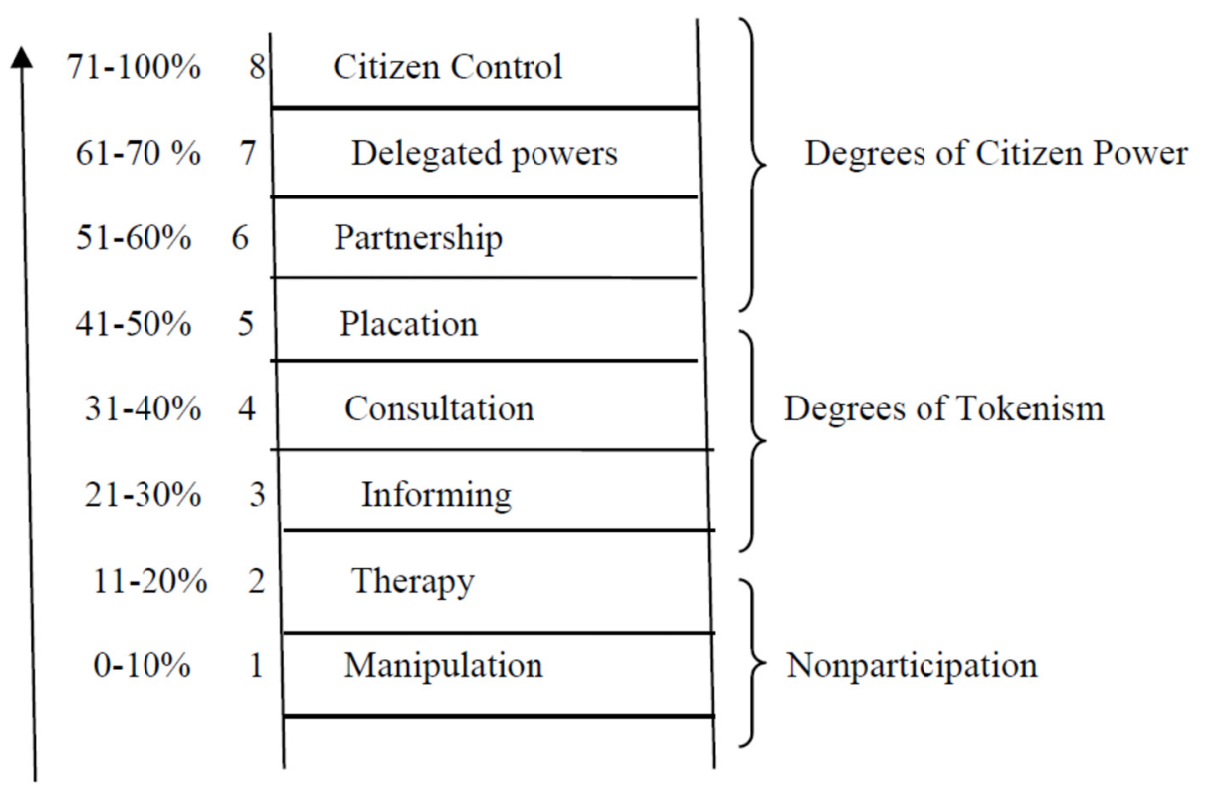

Figure 1. Modified version of Arnstein's ladder

The levels overlap as one move from non-participation to citizen control. The stages are further indicated by the arrow on the left of the ladder. The percentages between the arrow and the numbers 1-8 were introduced as a measuring tool to determine levels of participation when analysing the data. If a measured level of participation falls between $0-10 \%$, the conclusion will be a manipulative and non participatory process. Surely, a measured participation level of $71-100 \%$ would indicate the highest degree of citizen power-that is, citizen control from Arnstein's classification. Together, the first two levels describe what Arnstein refers to as the degree of 'non-participation' that is dominated by the manipulative practices of policy makers. Policy makers at these two levels do not want to enable actual participation of the have-nots in the national development planning processes. Their intentions under such circumstances are what Arnstein refers to as to 'educate or 'cure'- that is, totally controlling the development planning processes from the top $(1969,217)$.

Group together at various overlapping degrees are the third, fourth and fifth levels that fall under the descriptive category of 'tokenism'. Although under the third and fourth levels there are some consultations and information flow from the top, the have-nots lack the power to influence or alter the national development planning process in any form. Hence, the status quo remains since information flow is only in one direction, from the top. Although it is possible that the have-nots might move to an advisory position under level five (placation), they have no rights or power to make decisions. Decisions are once again made from the top $(1969,217)$.

At the sixth level, the have-nots start to exert some influences on the top and might start to influence national development policies by entering into trade-offs. Partnerships develop at this level and the effects of citizen participation start becoming obvious. The degree of citizen power that started under the sixth level becomes more pronounced under the seventh and eight levels as gradually, delegated authority becomes very evident and, the continuous effects of participation start to lead to bottom up contributions and ultimate control. Arnstein states with reference to citizen control at the eight level: 'have-nots citizens obtain the majority of decision-making seats, or full managerial power' $(1969,217)$ in the development planning process.

\section{Research Methodology}

Systematic review is the methodological base of this paper. The justifications for using this tool are twofold. First, there already exist large volumes of work on Ghanaian development plans, the plan making processes and the plan making environment. Second, the four development plans under analysis in this study like all national policy texts are institutional, with institutional authors. Although institutions are like humans in that they can claim existence, they can be addressed and spoken of, institutional authors do not exist as human authors. Hence, faced with the task of deducing meanings or in the case of this study measuring participation from institutionally authored texts, researchers find themselves dealing directly with the objectives, activities, clauses and sentences 
of documents (Owusu 2014).

Systematic reviews are useful for identifying, analysing and synthesising existing research (Alston \& Bowles 2013; Victor 2008). Norton states that systematic reviews 'are a method of collating and bringing together large amounts of information and using this available evidence to answer different types of questions ...' $(2008,381)$. The question this paper seeks answer to is how participatory were the plans and planning processes? Three major forms of systematic reviews exist. Traditional reviews that make extensive use of randomised controlled samples and statistical analysis and, the integrative approach that focuses on theory development. The third form, the mixed method or extended review which this paper adopts focuses on processes and people's perceptions. Further, the mixed method makes use of varying qualitative researches and it accommodates a narrative form of synthesis and analysis (Alston \& Bowles 2013; Victor 2008).

Systematic reviews are very purposeful and structured and can be replicated like all scientific methods. Norton outlines the following criteria for any successful systematic review: the aims and objectives of the review are clearly provided, there is an adequate description of the context in which the research is being undertaken (including a rationale for why the study is being pursued), there is an adequate description of the samples used and the methods for how the samples were identified and recruited, there is an adequate description of the methods used to collect samples and there is an adequate description of the methods used to analyse the data (2008, 383-384).

The review would be carried out within the perimeters of the developed modified version of Arnstein's ladder. Although actual physical participation or non-participation is central to contemporary development planning practice, the overall focus of the review would be about determining the level of participation as measured from the four policy texts. The levels of participation from the four policy documents serves as the measuring bench mark for actual participation during implementation. The policy matrixes of the plans that contained policy themes, policy issues, policy objectives and policy activities/strategies would serve as the basis of the review. The only difference will be with the Ghana Vision 2020 where the review will be done by an analysis of sections three, four and five of the plan. The selected sections contain the policy objectives, activities and issues of Vision 2020. Vision 2020 does not have a policy matrix.

The intentions and intended actions of policy makers to engage the have-nots in development planning decision are documented in policy issues, themes, objectives and activities. A policy objective is any specific policy outcome to which an activity or several activities are aimed at achieving. A policy activity is the policy measure or measures specifically directed at achieving the objective/s' (Owusu 2014, 3). Policy issues are constraint/s identified as hampering local development. These constraints normally inform policy objectives and activities. A policy theme is the primary subject under analysis. It contains the policy issues, objectives and activities. Through the occurrences in the texts of the policy matrixes and sections three, four and five of Vision 2020 of the following words and phrases: participation, involvement, local involvement, community involvement, engagement, citizen power, citizen control, local consultation, local planning and bottom up planning, the measurement will be carried out. The total occurrences of the above participatory terms within the texts will be matched against the combined total of policy areas, issues, objectives and activities in order to measure the level of participation. Although the context within which the selected participatory terms occurred could be contextually significant, the review only focused on the physical occurrences of the selected words or phrases. Any amount of occurrence/s, whether one or more will be the yardstick for determining participation or non-participation. The more the occurrences, the more the degree of participation and more importantly, the more the degree of intended participation.

\section{A History and Culture of Top Down Planning}

Ghana's history of documented development planning and plans dates back to 1920 when a Ten Year Development Plan (1920-1930) was launched under Gordon Guggisberg, the colonial British Governor of the Gold Coast, now Ghana (Ewusi 1973, 1; Kay 1972, 41 \& 53-59). The period of implementation of that plan was 1920-1927 (Ewusi 1973, 1). As it became the pattern under colonialism, 'the colonial administration diagnosed the weakness of the economy' (Kay 1972, 42). The colonial administration singled out transportation as the major weakness of the economy. About seventy five percent of budgetary allocation under the Guggisberg's plan was for transportation (Kay 1972, 42). The Guggisberg plan also resulted in the construction of some health centres (Huq 1989, 6). Early British colonialism in Ghana was a period of absolute therapy and manipulation, where non-participation was the administrative principle. Citizen participation as the redistribution of power that enables the have-nots and locals to be deliberately included in the development planning process was absent. British colonialism was not a participatory and/or democratic phenomenon in all spheres, development planning 
inclusive.

There is no evidence to indicate that the locals participated in any form in whatever decision making and/or planning processes that existed during colonialism. Howard provides an excellent insight into this non-participatory situation under colonialism in Ghana. She states: 'a European club in Accra was the focus of social events; no African were permitted into the club until independence in 1957. Here decision could be made over cocktails at sundown, later to be translated into government language for the benefit of the Africans' (1978, 147). British colonialism 'was not merely undemocratic; it was anti-democratic', exclaims Kwarteng (2011, 7). Not even Lugard's indirect rule system can stand out as an exception in this respect. Adu Boahen agrees, stating that indirect rule was 'in reality, the most indirect way of ruling directly' (quoted in Briggs 2010, 19). Participatory planning did not stand a chance under indirect rule, control from the top was the status quo.

The basic principle underlying indirect rule as presented by Lugard and practiced in Uganda, Nigeria and other colonists was to allow traditional chiefs to continue ruling locally, but under the direct supervision of the colonial masters (Briggs 2010, 19). Colonial administrators mastered the art of manipulating and controlling local chiefs from the top and the ease of imposing direct rule indirectly through them. Amongst others, Apter outlines the following principles as key to indirect rule - the right to legislate is reserved for the colonialist, the right of conforming or otherwise deciding on a successor chief is reserved for the colonial governor and the right to appropriate land for planning purposes is vested in the colonial governor $(1972,121)$. Where in lies any form of bottom up planning if the locals had no say in the appropriation of their land. Apter further argues that indirect rule shifted 'the focus of authority and responsibility away from the legitimate properties of chieftaincy to those of British power. An immediate consequence was to identify the chiefs as agents of British rule' $(1972,122)$.

Briggs maintains that indirect rule as it was administered in the Gold Coast undermined the very institution it was intended to protect because, chiefs owed their authority to the colonial masters through their appointment process (Briggs 2010,19). Apter agrees and argues that 'the most disruptive element of all was introduced by transmuting traditional legitimacy into legitimacy derived from Great Britain' (1972, 123). Referencing Deschamps' Lugard Memorial Lecture, Crowder argues that the practice of using chiefs as the modus operandi of indirect rule made the practice very similar to the French Assimilation. He concludes: 'far from what is generally supposed, the two were in practice very similar, since they both reposed on indigenous chiefs' (1964, 197). If the French were aimed at 'making Africans French under Assimilation', the British were aimed at 'making Africans British under Indirect Rule' and, not aimed at participatory planning. The British were top-down and non participatory in practice. They ensured that there was always a clear distinction between those at the top and those at the bottom. In each colony Kwarteng argues, 'there were highly detailed tables of precedent, which showed exactly where everyone stood in the pecking order' $(2011,4)$. And in that pecking order in development planning terms, the locals were always at the bottom. Under such circumstances and culture, participatory planning under colonial rule was a mirage. Colonialism's top-down nature was graphically represented in planning and plan making.

One other named Ten Year Development Plan (1946-1956), the Plan of Development and Welfare of the Gold Coast was drawn and crafted from the centre under direct colonial rule and implemented only during 1946 (Ewusi 1973, 1). A third Ten Year Plan for the Economic and Social Development of the Gold Coast (1951-1961) implemented only in 1951 was launched just before self-government later that year (Ewusi 1973, 1 \& 5). The plans and planning processes from Guggisberg till self-government never deviated from the top-down approach. Killick agrees arguing that those plans and the planning processes, including those developed by Nkrumah and his Convention People's Party (CPP) were top down and no different from those of the colonialist they had fought to dislodge $(1978,34)$.

In an attempt to provide a justification for Nkrumah and his CPP adopting the colonial approach to planning, Ewusi provides an excellent supporting argument for the top down nature of planning after self-government in 1951. He states: 'there are practical reasons to explain why the Convention People's Party government adopted the colonial planning techniques. For one thing, there were no African specialists with the expertise to formulate sophisticated plans. Also, Ghana was still more or less a colony and her policies had to be approved by Britain. It is not surprising, therefore, that the Nkrumah government adopted the first plan in toto' (1973, 5). Ewusi concludes: 'Nkrumah was 'seeking first his political kingdom' and the niceties of planning were not given prime consideration" $(1973,6)$. With the niceties of planning placed firmly at the back burner from Guggisberg to self-government, all governments during that period operated by absolute control from the top. It is not a difficult decision to assign the period from Guggisberg to self-government Arnstein's non-participation levels, where the mode of planning was totally manipulative. After independence in 1957 and in the midst of the excitement and confusion, a Consolidated Plan covering the period 1958-1959 was launched (Ewusi 1973, 1). It 
is rather unclear as to what a year's development plan sought to achieve. Two years after independence in 1957, a Second Five Year Development Plan covering the period 1959-1964 was launched by Nkrumah and his CPP (Ewusi 1973, 1 \& 7). Although coming from the Development Commission, a Standing Development Committee and contributors like Arthur Lewis (Ewusi 1973; Killick 1978), Fitch and Oppenheimer maintained that the plan 'gave the appearance of breaking with the colonial past when in reality it had not' (quoted in Biney 2011, 101).

The Second Five Year Plan period of formulation and subsequent plans under Nkrumah coincided with what Killick calls 'a shifting balance of power within the ruling party and a movement towards more radical policies' $(1978,36)$. This wasn't a shift away from control from the top, absolutely not. It was a shift towards more controlling the development planning process by Nkrumah and his CPP. This move was clearly exemplified by a speech Nkrumah delivered in 1959 where he 'placed more stress and urgency on socialism as an ideology of the CPP' (Killick 1978, 36). Not on participatory democracy that could have over time had the prospect of translating into participatory planning. Rather, it was on Nkrumah's Socialism/African Socialism.

For Nkrumah, 'modern socialism required a centralized form of government to direct the operation and development of the economy...the state would be fundamental in Ghana's "big push" for industrialization, economic growth, and the creation of socialism' (Biney 2011, 107). With the state being positioned to play a fundamental role, planning from the top became ultimately the planning method. Government direct involvement in the organization of economic activities was encouraged and perpetuated. This top-down approach to planning was brought into perspective by Nkrumah's own words. He said: 'the domestic policy of my government is the complete ownership of the economy by the state' (Killick 1978, 38). With no stated official reason, the then ruling Convention People's Party government of Nkrumah abandoned the plan in 1961. However, Nkrumah's visit to the Soviet Union, China, Yugoslavia, Romania, Bulgaria, and Albania between July and September of 1961 add lots of meaning to the development planning narrative of the early 1960s (Biney 2011, 104).

The replacement of the Second Five Year Development Plan in 1961 could be rightly attributed to the changing political ideology of the ruling CPP government. The democratically elected CPP government within the prevailing multi-party political environment had started to adopt a one party communist mentality. That new communist position was totally compatible with planning from the top. Nkrumah political statements and actions indicated that he was on the path of cementing planning from the centre and building a society in Ghana based on Marxism. With Nkrumah Marxist and Communist posturing, top-down approach to development planning in Ghana became the status quo under the CPP. With this adopted Marxist philosophy, in 1964, the Constitution was amended and Ghana made a one-party state with Nkrumah its life president. Any hopes of participatory bottom up planning were dashed by this singular act of Nkrumah.

The top down posturing of Nkrumah and his government were clearly reflected in the CPP's Programme for Work and Happiness introduced in 1962 as a replacement to the Second Five Year Development Plan. The programme further cemented the top-down approach to development planning and the control of the state. Paragraph 55 of the programme states: 'the basic aim of our economic development is to free our economy from alien control and for the state to participate in the wholesale and retail sectors of trade throughout the country. This party is firmly of the view that planning of the national economy can only be really effective when the major means of production, distribution and exchange have been brought under the control and ownership of the state' (Programme for Work and Happiness 1962). Beyond the political objectives and rhetoric of the programme, the state controlled from the centre by becoming directly involved in various forms of economic, agricultural and industrial activities. The creation of state owned agricultural units and plantations known as the Workers Brigade were clear manifestation of a state perpetuated top-down approach to development planning.

In 1963, The Programme for Work and Happiness was replaced with a Seven Year Development Plan 1963-1971 (7YDP 1963). The political and ideological underpinnings of the Programme and the top-down approach to development planning were maintained by the new plan. That should not be a surprise because Nkrumah was still in power. The desire of Nkrumah to solve the country's poverty and unemployment problems by planning from the centre was clearly evident in the Seven Year Development Plan. In accordance with the prevailing Marxist ideology of Nkrumah's CPP, the government progressively acquired a controlling role in the economy through its direct investments in the industrial and agricultural sectors (7YDP 1963 3, 19-20). Under circumstances where Nkrumah's desires and ambitions were contrary to the plan, he imposed his will. On one of such occasions, Nkrumah was known to have retorted - 'Who decides, Mensah or me'? (Biney 2011, 110). Mensah headed the planning commission. What an evidence of a government controlling the development planning process from the centre. 
The overthrow of Nkrumah's CPP government in February 1966 by a police cum military National Liberation Council (NLC) administration ended the plan. By the time of the coup in 1966, the economy had started to experience some difficulties. The CPP government had started seeking advice from the IMF and the World Bank from May 1965. The 1966 coup occurred against the background of negotiations occurring between the CPP, the IMF and the World Bank. Though no official agreement had been reached between the parties at the time of the coup, contacts between the NLC, the IMF and the World Bank continued. In any case, the involvement of the IMF and the World Bank at that early stage of Ghana's development would not have changed the country's top-down approach to development planning. An ideological shift in economic policies occurred with the NLC government. This shift was demonstrated by the government actions and reflected in the Two Year Plan 1968-1970, named 'From Stabilization to Development'. The plan title is clearly showing some early influence of the IMF.

Prior to the formulation of that plan, economic stabilization had never been a committed policy focus of previous national plans. The NLC opened up the economy and encouraged private involvement in productive activities. This was a major break from Nkrumah. The NLC's stated objective was to gradually disengage the state from economic activities. On the contrary, Naylor maintains that the NLC 'polices were not substantially different from those pursued by the CPP' $(2000,20)$. Development planning under the NLC exhibited some form of 'tokenism'. The development planning process under the NLC showed signs of graduating from manipulation and therapy to informing and consultation because of the government's attempts at opening up the economy to private investments. Under tokenism, citizens are being heard although they lack the capacity and power to influence the planning process. It is unclear as to whether the attempt at opening up the economy was a direct result of citizens' power and participation or the result of IMF conditions and pressure.

It is emphasized here that any form of graduating from level two to three on the ladder during the NLC's period was not a result of citizens' power because the NLC was a military government and, soldiers are not democratic. The attempted graduation being discussed here is attributed to the influence of the IMF and the World Bank. Awoonor states that immediately after the NLC came to power, 'the International Monetary Fund and the World Bank resumed their ties with Ghana, granting her immediate short term loans amounting to $£ 10$ million' (1990, 212). Akonor went further by listing several conditions from the IMF the NLC had to comply with between 1966 and 1969 in order for a working credit relationship to be maintained. He refers to the devaluation of the Cedi, ceiling of the Central Bank credit to the government and commercial banks $(2006,26)$. In any case, participation at the informing and consultation levels does not in any form allow the have-nots/locals views to be heeded by the top. Graduation during that period cannot even be placed at the level of placation where the ground rules allow the have-nots to advise the top. Again, this was a period of a military government and solders don't take lectures from civilians. If they did, at the barest minimum, they would not have overthrown an elected civilian government. A year after the plan was commissioned, the NLC ended its governance by reinstating constitutional rule in October 1969. The Progress Party of Busia was elected into office.

Busia's government continued a working credit relationship with the IMF and 'attempted to deepen the liberalization and privatization' (Hutchful 2002, 10) started by the NLC. This working credit relationship led the IMF to push for further devaluation of the cedi, over 40 percent by 1971 (Hutchful 2002, 11; Akonor 2006, 27). Despite Busia's attempt at privatization, the top down nature of development planning still featured prominently in activities and policies of the Progress Party. Killick agrees arguing that 'in spite of an apparently positive attitude to the free operation of market forces, a large role was also envisage for the state' $(1978,56)$. Although democratically elected into office, there is no evidence of a bottom up participatory planning under Busia. Within the perimeters of Arnstein and in development planning terms, Ghana still found itself lurking between the second and third levels of the ladder under Busia. The Progress Party administration was however short lived. On January 13, 1972, after less than two and a half years in office, the government was overthrown by Colonel (later General) Acheampong.

The National Redemption Council (NRC) military government came to power. The NRC moved the country to stricter controls, similar to those witnessed under Nkrumah's CPP. In essence, that move should not have been a surprise as 'Acheampong had received some training at Nkrumah ideological institute in Winneba' (Brydon \& Legge 1996, 11). Any attempts at further graduation on the ladder from consultation to placation and beyond were dashed by the policies and actions of the NRC. That coup moved Ghana back to the bottom of the ladder, from apparent tokenism to non-participation. The policies and actions of the NRC support this position. A return to the task of creating a command economy was again started. The local currency was re-valued by the state. The military government returned to import and price controls. The soldiers further stated that they would reactivate various state enterprises left uncompleted or abandoned after Nkrumah (Hutchful 2002, 11; Killick 1978, 316). 
Akonor provides this insight into the development planning philosophy of Acheampong by stating that the NRC focus was 'to use state power to capture the commanding heights of the economy and to control it...' $(2006,29)$. With this development ideology and top down approach to planning dominating government policies, the NRC formulated its Five Year Development Plan.

The NRC's Five Year Development Plan 1975-1980 (5YDP 1975) further cemented its top-down approach to development planning. State participation in all aspects of the economy was encouraged. The openness of the economy and private participation in economic activities were considered a constraint to national development (5YDP 1975, 16). The government increased its investment in the agricultural sector and in the economy as a whole (Akonor 2006, 29: Brydon \& Legge 1996, 11; Hutchful 2002, 9; 5 YDP 1975, 21). The plan stated: 'in the next few years, heavy injection of capital ranging from simple agricultural tools to tractors, combine harvesters and irrigation works are expected to be made in support of the Operation Feed Yourself and Industries Campaigns' (5YDP 1975, 33). Government involvement in the economy moved beyond the establishment of factories to the provision of storage facilities, both on and off farms, warehousing and other marketing infrastructures in the distributive trades (5YDP 1975, 34). No aspect of the national economy was free from state involvement. The implementation of the NRC's Five Year Plan like past ones was affected by another military take-over. The NRC internally changed twice before the coup that overthrew it. In October 1975, the NRC transformed itself into a Seven-Man Supreme Military Council (SMC). Three years later in July 1978, a 'Palace Coup' occurred and the SMC was replaced with the SMC II (Akonor 2006, 29). The SMC II announced a programme to return the country to democratic constitutional rule by holding elections on June 18, 1979. Before it could implement its electoral programmes, the SMC II was overthrown on June 4, 1979 (Hutchful 2002, 13).

Overthrowing the SMC II in 1979, the Armed Forces Revolutionary Council (AFRC) came to power. The AFRC did not change the process of returning the country to civilian rule. Elections were held on June 18, 1979 as planned by the SMC II. Three months later on September 24, 1979, the AFRC left office and handed power to the newly elected People National Party (PNP). The new civilian PNP government of Hilla Limann was in office for about two years. The military ruler (Jerry Rawlings) that handed power to the PNP took back power in December 1981. The December 31, 1981 coup brought the Provisional National Defence Council (PNDC) to power. The PNDC military government remained in power until democratic civilian rule was restored in 1992. The very fluid and unstable political climate in Ghana from the end of the SMC II in 1979 to the start of Structural Adjustment in 1983 under the PNDC military government might be the reason why no formal attempt at national development planning occurred. Although no development plan existed or were formulated, the soldiers governed from the top. Citizen's participation in development planning was totally absent during this fluid period of Ghana's history. In the absence of a constitution and any structured approach to planning, the soldiers ruled and planned from the centre by decrees.

\section{Data and Analysis}

Ghana again entered the period of formal national development planning and plans after the country returned to constitutional rule in 1992. Articles 86 and 87 of the 1992 Constitution created the NDPC. Constitutional Acts 479 and 480 provide the NDPC's mandate of advising the president on development planning matters. The NDPC is part of the executive. Article 36, clause 5 of the 1992 constitution states that "within two years after assuming office, the president shall present to parliament a coordinated programme of economic and social development policies, including agricultural and industrial programmes at all levels and in all the regions of Ghana'. As a part of the executive, the NDPC is the body charged with producing national development plans on behalf of the presidency. The constitutional position of the NDPC is not under analysis in this paper. However, Article 36, clause 5 and Acts 479 and 480 provide the basis for continuous planning from the top at all levels in Ghana, a country with a deep tradition in central planning.

Coming first out of this new constitutional arrangement was the document now referred to simply as the Ghana Vision 2020 (The National Development Policy Framework -NDPF) and the Co-ordinated Programme of Economic and Social Development Policies - CPESDP (The First Step: 1996-2000). Although not a national development plan, the Vision 2020 is a major referenced national planning document. Hence, its consideration and analysis in this paper. Vision 2020 contained what is referred to as 'guidelines' for the formulation of sector and local level plans. The NDPF articulates the long term (25 years) 1996-2020 development focus of the country. The NDPF and its guidelines should serve as the basis for the preparation of the first set of development plans at all levels of the planning milieu in Ghana according to section 1.3.

Vision 2020 is structured around the following five major policy themes: human development, economic growth, rural development, urban development and enabling environment. As per NDPC guidelines, all districts and 
sectors plans were to be framed around these five themes. Not being a development plan, the Vision 2020 had no policy matrix. Therefore the analysis of this document was carried out by a review of Section 3 (long term objectives), Section 4 (objectives, opportunities and constraints) and Section 5 (objectives of the medium term programme). Table 1 below computed from Vision 2020 provides a summary of the review.

Table 1. Summary of Vision 2020

\begin{tabular}{cccccc}
\hline Policy Theme & Policy Areas & Objectives & Activities & Total Ref. to Participation & \% of Participation \\
\hline Human Dev't & 11 & 69 & 74 & 13 & 8.44 \\
Econ Growth & 9 & 51 & 48 & 5 & 4.62 \\
Rural Deve't & 3 & 20 & 10 & 2 & 6.06 \\
Urban Dev't & 3 & 16 & 7 & 1 & 3.84 \\
Enabling Envir & 8 & 37 & 22 & 6 & 8.95 \\
Totals & $\mathbf{3 4}$ & $\mathbf{1 9 3}$ & $\mathbf{1 6 1}$ & $\mathbf{2 7}$ & $\mathbf{3 1 . 9 1}$ \\
\hline
\end{tabular}

Source: Vision 2020

Although the five major policy themes, particularly human development, rural development, urban development and enabling environment connote some form of participatory processes for success, no direct reference to participation, community involvement, citizen or local participation or bottom up planning was made within the themes. Sub themes like population and the disadvantaged persons under human development provided useful avenues for participatory planning. However, those themes made no reference to local level involvement of any kind

Interestingly, the economic development theme give a glimpse of some form of local involvement by making reference to the equitable distribution of the benefits of development and closer integration of women and rural dwellers into the national economy and the elimination of poverty. However, the means by which districts and sectors were to plan in order to achieve that objective made no direct reference to citizen participation. Instead, the objective was to be achieved 'through the promotion of efficient rural farm and nonfarm production activities and the encouragement of the innovative spirit of micro and small enterprises (MSEs)'.

Overall medium term objectives for the period 1996-2000, theme specific medium term objectives and guidelines specific to each policy area appearing in the NDPF were also analysed as part of the review. No reference to local involvement as a medium term objective mentioned under human development. An extended objective under the same policy area focused on family planning and fertility control with no direct reference to local involvement. The guidelines for setting medium term human development objectives and activities also made no reference to community participation.

The trend of no direct policy reference to participatory planning is reflected under both objectives and guidelines of the economic growth theme. Although economic policies are a central government's primary domain, any reference to direct involvement of businesses or local planning authorities in decisions that affect them would have be an indication of the development planning direction of the state. A vague reference to 'decentralisation of decision on expenditure' is made in the text. A more direct objective on fiscal decentralisation would have been a clear manifestation of the government intended policy direction.

Under the rural development theme, a detailed analysis of the nature and structure of Ghanaian rural communities was provided. However, the medium term rural objectives made no mention in any form to participation as a policy option. A reference to community participation appeared under guidelines for rural development planning. The objectives and guidelines under urban development made no reference to community participation. The review of the enabling environment theme provided a range of results. First, there were no general theme specific objectives. This was a deviation from the general trend of the document. With no theme specific objectives, no reference to participation was also made. Apart from the sub-theme of law and regulation, the remaining enabling environment sub-themes; governance, capacity building, culture and public administration at the national and local levels all had references made to participation in one form or the other.

Table 1 shows the individual figures and percentages as computed from Vision 2020. All major policy themes had a percentage of participation of less than $10 \%$. A percentage total of less than $10 \%$ indicates broad 
non-participation and specifically absolute manipulation from the revised ladder. When added up however, the combined total of $31.91 \%$ moved the Vision 2020 to level four - consultation on Arnstein's ladder. In any case, consultation falls under the descriptive category of 'tokenism'. Under 'tokenism', Arnstein maintained that although there might be some form of consultation and information flow from the top, the have-nots lack the power to influence or alter the national development planning process in any form. Information flow and decision making is only in one direction, from the top. Following Vision 2020 was the Ghana Poverty Reduction Strategy (GPRS) 2003.

The focus of the GPRS 2003 in theory was on poverty reduction as indicated by the document on several instances. This apparent focus on poverty reduction is being attributed to Ghana's adopting the Heavily Indebted Poor Countries Initiative (HIPC). The focus on poverty reduction was expected to continue as long as Ghana was under the HIPC regime. Like the Vision 2020, the GPRS 2003 was to serve as the basis for district or sector development plans. The GPRS 2003 was framed around the following five themes; macroeconomic stability, increasing production and gainful employment, human development and provision of basic services, special programmes for the vulnerable and excluded and good governance.

Provided on pages 6-12 of the GPRS 2003 is an elaborate list of groups, institutions and individuals consulted and, activities undertaken with dates at both the national and local levels when preparing the document. Based on pages 6-12, it would not be difficult to conclude that the process of preparing the GPRS 2003 was very participatory. However, the results obtained from reviewing the actual objectives and activities in terms of the level of citizens' involvement is non-participatory. The section on macro-economic policy showed no evidence of intended local involvement in the actual implementation processes. Granted, issues of macro and micro economic management are the preserve of central governments. In a democracy like Ghana however, there are and there should always be opportunities for participatory planning regardless of the policy area. For instance policy objective 1.2 'improve expenditure management' and 3.2 'diversify export base' provided excellent opportunities for participatory planning because of the indicated policy activities. The policy activity for objective 1.2 for instance had what can be described as an inherently participatory activity - that is, tracking poverty related expenditure. Yet, no mention of local involvement in this activity.

The six policy areas and ten policy objectives under the production and gainful employment theme were non-participatory in nature with no reference to citizens' involvement. However, the fifth activity under objective 4.1 mentioned community involvement as a strategy for environmental and natural resource management. This was the only reference to participation out of forty five different activities under this theme. A direct reference to local involvement under the activities of policy area 5 (non-traditional export development) would have been very appropriate because of the policy focus. However, no direct reference to local involvement in the seven activities outlined.

Despite having policy objectives that would readily call for local involvement, like 1.1 increase access to education and training, 3.1 prevent new transmission of HIV and 3.2 provide continuum of care for people living with HIV and AIDS, the overall sixty three activities and 13 objectives of the human resources and basic services theme made no reference to citizens' participation. The pattern of no direct or indirect reference to local involvement in policy activities continued under the vulnerable and excluded theme. Table 2 below provides a statistical summary of the results obtained from reviewing the GPRS 2003.

Table 2. Summary of GPRS 2003

\begin{tabular}{lllllll}
\hline Policy Theme & $\begin{array}{l}\text { Policy } \\
\text { Areas }\end{array}$ & Objectives & Activities & $\begin{array}{l}\text { Total } \\
\text { Participation }\end{array}$ & to & $\begin{array}{l}\text { \%o } \\
\text { Participation }\end{array}$ \\
\hline $\begin{array}{l}\text { Macro-economy } \\
\text { Production and Gainful }\end{array}$ & 3 & 7 & 20 & 0 & 0 \\
$\begin{array}{l}\text { Employment } \\
\text { Human Res. Dev. \& Basic }\end{array}$ & 6 & 10 & 45 & 1 & 1.64 \\
$\begin{array}{l}\text { Services } \\
\text { Vulnerable and Excluded }\end{array}$ & 2 & 13 & 63 & 0 & 0 \\
Governance & 4 & 4 & 19 & 0 & 0 \\
Totals & $\mathbf{2 1}$ & $\mathbf{4 3}$ & $\mathbf{1 9 2}$ & $\mathbf{2}$ & 1.72 \\
\hline
\end{tabular}

Source: GPRS 2003 
Out of 235 policy objectives and activities of the GPRS 2003 from table 2, only twice were references made to participation. Three policy themes scored zero in terms of references to participation. The two calculated percentages of participation from table 2 are all less than $10 \%$. The combined total of percentage of participation is also less than $10 \%$, thus placing the GPRS 2003 at the bottom of the ladder where the rules are manipulation and non-participation. The manipulative practices of policy makers at this level lead to total control from the top. The Growth and Poverty Reduction Strategy (GPRS) 2006 followed the GPRS 2003.

The GPRS 2006 covered the period 2006-2009. Although similar in many aspects to the GPRS 2003, there are noticeable differences between the two documents. My focus is on the structure of the policy matrices. Apart from being the reference point of the review, the matrices also informed the configuration of the summary tables. A new column - issues was included in the GPRS 2006. Issues referring to identifiable problems. It is unclear from the document as to whether the issues informed the policies or vice versa. This is the case because fiscal policy management, international trade management, monetary policy management, private sector development policies 5-11 and several other policies have no issues. There are instances within the text of the GPRS 2006 where a policy is aimed at addressing multiple issues that appeared in some cases unrelated, vague and ambiguous. Policies 2 under 'private sector development' and 1 under 'agriculture led growth' with 17 and 21 issues respectively are examples. Key area 'enhancing development communication' showed another trend, an issue with 4 policies.

Like its predecessor, the GPRS 2006 on pages 9-12 detailed the processes embarked upon before the plan was authored. From the Cross Sectoral Planning Groups (CSPGs) formed around the five themes of the GPRS 2003 to the narrowed down three priority areas, namely Private Sector Competitiveness, Human Development and Basic Services and Good Governance and Civic Responsibility, the process of formulation appeared participatory. CSPGs were composed of state and non-state actors drawn from government departments, professional bodies, tertiary institutions, research institutions, non-governmental organizations, community-based organizations, organised groups and associations (TUC, Federation for the Blind \& Disabled), development partners and the list goes on. However, the review showed a familiar trend, non-participation. The results are presented below in table 3 .

Table 3. Summary of GPRS 2006

\begin{tabular}{|c|c|c|c|c|c|c|}
\hline Policy Theme & $\begin{array}{l}\text { Policy } \\
\text { Areas }\end{array}$ & Issues & Objectives & Activities & $\begin{array}{ll}\text { Total Ref. } & \text { to } \\
\text { Participation } & \end{array}$ & $\begin{array}{l}\% \text { of } \\
\text { Participation }\end{array}$ \\
\hline $\begin{array}{l}\text { Private Sector } \\
\text { competitiveness }\end{array}$ & 8 & 209 & 79 & 362 & 16 & 2.43 \\
\hline $\begin{array}{l}\text { Human Dev't \& Basic } \\
\text { Services }\end{array}$ & 9 & 40 & 49 & 225 & 8 & 2.47 \\
\hline $\begin{array}{l}\text { Good Gov’t \& Civic } \\
\text { Responsibility }\end{array}$ & 15 & 64 & 67 & 156 & 15 & 5.00 \\
\hline Totals & 32 & 313 & 195 & 743 & 39 & 9.90 \\
\hline
\end{tabular}

Source: Computed from GPRS 2006

The GPRS 2006 had a percentage of participation of 9.90, making it a completely non-participatory document. With a calculated percentage of less than 10\%, the GPRS 2006 finds itself at the bottom of the ladder where there are no rules of engagement, only manipulative practices from the top. Although having a combined total of 1,251policy objectives, activities and issues, references to participation were made only 39 times within the document, leading to a percentage score of below 10. Two major conclusions are drawn from comparing tables two with three. Either Ghanaian policy makers in 2005 understood more fully the diversity and complexity of the country's challenges by the 313 identifiable issues or that Ghana had retrogressed significantly within just two years. From a relative low of 43 and 192 objectives and activities in 2003, the figure increased to 195 and 743 respectively in 2005.A further review of the levels of participation led to table 4 below. Activities dominated the incidents of participation with 29 occurrences. This is encouraging since activities are actions that presumably involve local participation. 
Table 4. Level of Participation in GPRS 2006

\begin{tabular}{llll}
\hline Policy Theme & Issues & Objectives & Activities \\
\hline Private Sector competitiveness & 3 & 3 & 10 \\
Human Dev't \& Basic Services & 0 & 2 & 6 \\
Good Gov't \& Civic Responsibility & 1 & 1 & 13 \\
Totals & $\mathbf{4}$ & $\mathbf{6}$ & $\mathbf{2 9}$
\end{tabular}

Source: Computed from GPRS 2006

Following the GPRS 2006 was the GSGDA 2010. The results of reviewing the GSGDA are presented in table 5 below. There was a huge jump in the measured level of participation from the GPRS 2006 to the GSGDA 2010. From a low of $9.90 \%$ in the GPRS 2006, the calculated percentage of participation increased to $28.62 \%$ in the GSGDA. Although encouraging, the increase is lower than the $31.91 \%$ achieved by Vision 2020 . Although encouraging, the increase only placed the GSGDA within the broader degree of tokenism from the ladder. With a score of $28.62 \%$, the GSGDA 2010 finds itself at the bottom of the degree of tokenism, the informing parameter. It is worth noting that under 'tokenism', the have-nots lack the power to influence or alter the national development planning process in any form. Under such circumstance, the status quo of non-participation remains since information flow is only from the top. Although the number of policy areas, issues, activities, objectives, total reference to participation and the percentage of participation in the GSGDA 2010 are all far higher than the GPRS 2006, both documents are non-participatory.

Table 5. Summary of GSGDA 2010

\begin{tabular}{|c|c|c|c|c|c|c|}
\hline Policy Theme & $\begin{array}{l}\text { Policy } \\
\text { Areas }\end{array}$ & Issues & Objectives & Activities & $\begin{array}{l}\text { Total Ref. to } \\
\text { Participation }\end{array}$ & $\begin{array}{l}\text { \% } \\
\text { Participation }\end{array}$ \\
\hline $\begin{array}{l}\text { Micro. } \\
\text { Stability }\end{array}$ & 4 & 16 & 12 & 54 & 0 & 0.0 \\
\hline $\begin{array}{l}\text { Priv. } \quad \text { Sector } \\
\text { Comp. }\end{array}$ & 6 & 52 & 13 & 84 & 1 & 0.65 \\
\hline $\begin{array}{ll}\text { Acc. } & \text { Agric. } \\
\text { Modern. } & \end{array}$ & 11 & 173 & 28 & 317 & 34 & 6.43 \\
\hline Oil \& Gas & 4 & 24 & 10 & 40 & 4 & 5.13 \\
\hline $\begin{array}{l}\text { Infra \& Human } \\
\text { Settl }\end{array}$ & 11 & 160 & 51 & 334 & 19 & 3.42 \\
\hline $\begin{array}{l}\text { Hum Dev't \& } \\
\text { Product }\end{array}$ & 15 & 84 & 30 & 139 & 21 & 7.05 \\
\hline Transp. Govern & 14 & 139 & 62 & 290 & 30 & 5.94 \\
\hline Totals & 65 & 648 & 206 & 1288 & 109 & 28.62 \\
\hline
\end{tabular}

Source: Computed from GSGDA 2010

Out of the 109 references to participation in the GSGDA, the majority (74) were activities from table 6 below. As with the GPRS 2006, this is again viewed as encouraging since activities are actions directed at goals. 
Table 6. Level of participation in GSGDA 2010

\begin{tabular}{llll}
\hline Policy Theme & Issues & Objectives & Activities \\
\hline Micro. Econ Stability & 0 & 0 & 0 \\
Priv. Sector Comp. & 0 & 0 & 1 \\
Acc. Agric. Modern. & 5 & 2 & 27 \\
Oil \& Gas & 2 & 0 & 2 \\
Infra \&Human Settl & 5 & 7 & 7 \\
Hum Dev’t \& Product & 1 & 2 & 18 \\
Transp. Govern & 6 & 5 & 19 \\
Totals & $\mathbf{1 9}$ & $\mathbf{1 6}$ & $\mathbf{7 4}$
\end{tabular}

Source: Computed from GSGDA 2010

\section{Conclusion}

The measured levels of participation from the four plans reviewed are summarized in figure two below. Although showing a fluctuating pattern from a high of about $32 \%$ for Vision 2020 to a low of about $3 \%$ for the GPRS 2003 , the four plans reviewed were all non participatory.

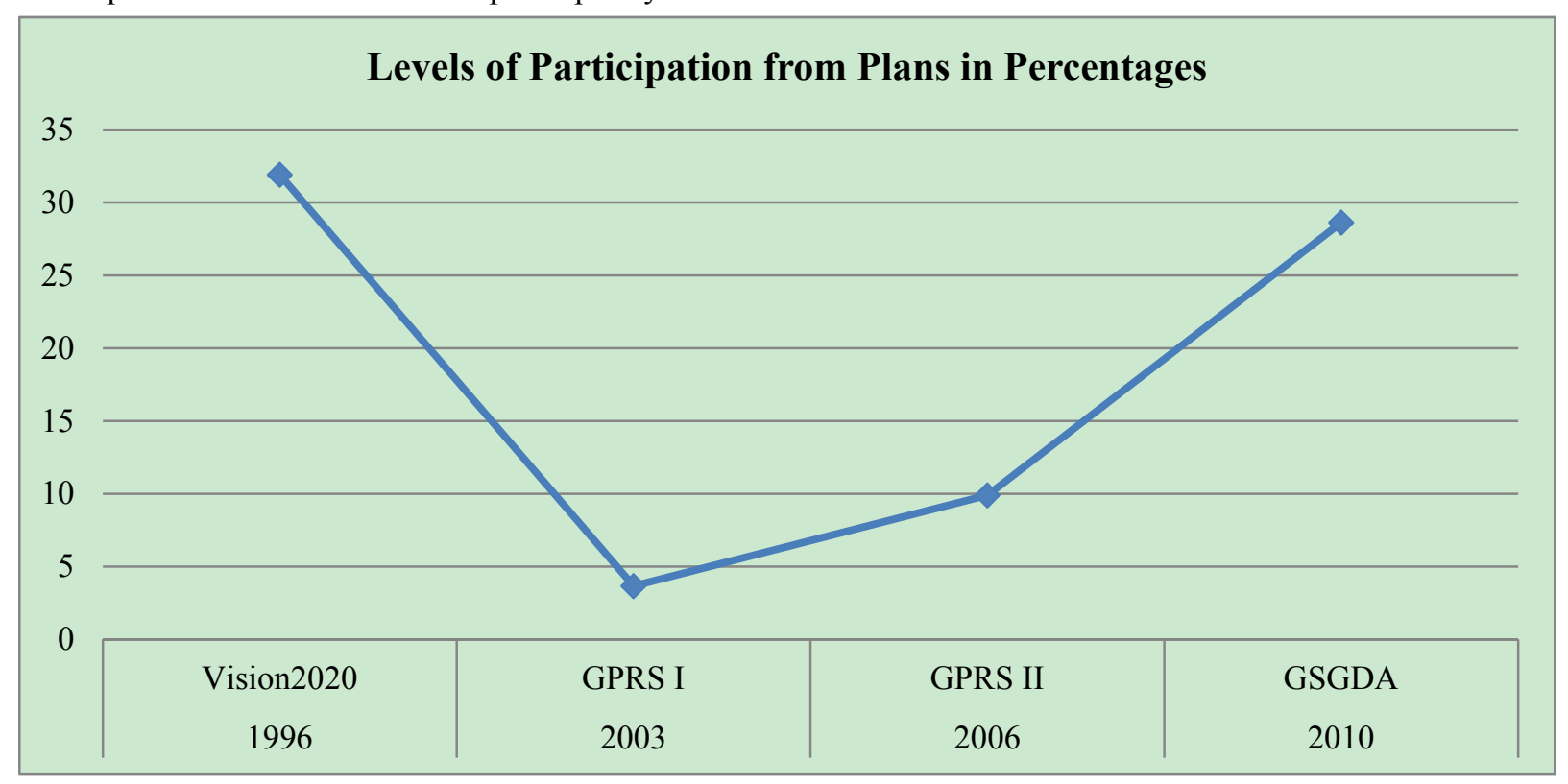

The highest score of about 32\% placed the Vision 2020at the informing level, the bottom of the broad category of tokenism, a non participatory level. What is encouraging from the review is that the measured levels of participation have showed a consistent level of increase since 2003. The challenge for Ghanaian planners is to maintain the momentum of increase over time. The following recommendations are here provided to sustain such a momentum.

Activities should be targeted for participatory actions. Activities are actions that must always involve some form of local involvement. The GPRS 2006 and GSGDA 2010 started the trend and this should be built upon in future plans. Additionally, the concept of local involvement and participation should be consciously built into policy areas, issues and objectives. If non participation is recognized as a constraint within a policy area, it should logically resurface as an issue, an objective and eventually as an activity. The concept and practice of decentralisation need to be revisited at all levels. It is difficult to reconcile the art of decentralisation in Ghana with the practice of the NDPC dictating the development planning agenda through stringent guidelines from the top. 


\section{References}

Akonor, K. (2006). Africa and IMF Conditionality. The Unevenness of Compliance, 1983-2000. London. Routledge.

Alston, M., \& Bowles, W. (2013). Research for Social Workers. An Introduction to Methods (3rd ed.). New York. Routledge

Apter, D. E. (1972). Ghana in Transition. Princeton. Princeton University Press.

Arnstein, S. R. (1969). A Ladder of Citizen Participation. Journal of the American Institute of Planners, 35(4), 216-224. http://dx.doi.org/10.1080/01944366908977225

Awoonor, K. N. (1990). Ghana. A Political History. Accra. Woeli Publishing Services.

Biney, A. (2011). The Political and Social Thought of Kwame Nkrumah. New York. Palgrave MacMillan. http://dx.doi.org/10.1057/9780230118645

Briggs, P. (2010). Ghana. $5^{\text {th }}$. Connecticut. The Globe Pequot Press.

Brydon, L., \& Legge, K. (1996). Adjusting Society: The World Bank, the IMF and Ghana. London. I.B. Tauris Publishers.

Burke, E. M. (1979). A Participatory Approach to Urban Planning. New York. Human Sciences Press.

Crowder, M. (1964). Indirect Rule-French and British Style. Africa-Journal of the International African Institute, 34(3), 197-205. http://dx.doi.org/10.2307/1158021

Dye, T. R. (2001). Top Down Policy Making. New York. Chatham House Publishers. http://dx.doi.org/10.4135/9781483330150

Ewusi, K. (1973). Economic Development Planning in Ghana. New York. Exposition Press.

Friedmann, J. (1987). Planning in the Public Domain: From Knowledge to Action. Princeton. Princeton University Press.

Government of Ghana. (1962). Programme for Work and Happiness 1962. Accra. Government of Ghana.

Government of Ghana. (1963). Seven Year Development Plan 1963-1971. Accra. Government of Ghana.

Government of Ghana. (1968). Two Year Development Plan. From Stabilization to Development 1968-1970. Accra. Government of Ghana.

Government of Ghana. (1975). Five Year Development Plan 1975-1980. Accra. Government of Ghana.

Government of Ghana. (1996). Ghana Vision 2020-The First Step. Accra. Government of Ghana.

Government of Ghana. (1996). Vision 2020 The First Step: 1996-2000. Accra. NDPC.

Government of Ghana. (2003). Ghana Poverty Reduction Strategy (2003-2005). An Agenda for Growth and Prosperity, 1. Analysis and Policy Statement. Accra. NDPC.

Government of Ghana. (2005). Growth and Poverty Reduction Strategy (2006-2009). Accra. NDPC.

Government of Ghana. (2010). Ghana Shared Growth and Development Agenda. Vol 1. Policy Framework. Accxra NDPC.

Howard, R. (1978). Colonialism and Underdevelopment in Ghana. London. Croom Helm.

Huq, M. M. (1989). The Economy of Ghana. The First 25 Years Since Independence. Basingstoke. Macmillan. http://dx.doi.org/10.1007/978-1-349-19749-1

Hutchful, E. (2002). Ghana's Adjustment Experience. The Paradox of Reform. Accra. Woeli Publishing Services.

Kay, G. B. (1972). The Political Economy of Colonialism in Ghana. A Collection of Documents and Statistics 1900-1960. Cambridge. Cambridge University Press.

Killick, T. (1978) Development Economics in Action: A Study of Economic Policies in Ghana. London. Heinemann.

Kwarteng, K. (2011). Ghosts of Empire. Britain's Legacies in the Modern World. London. Bloomsbury.

Masse, P. (1962). French Methods of Planning. The Journal of Industrial Economics, 11(1), 1-17. http://dx.doi.org/10.2307/2097824

Naylor, R. (2000). Ghana. Oxfam. London. http://dx.doi.org/10.3362/9780855987596 
Norton, M. (2008) Systematic Reviews. Can qualitative social work research live up to the Zeitgeist? Qualitative Social Work, 7(3), 381-386. http://dx.doi.org/10.1177/14733250080070030802

Owusu, V. L. (2009). The Making of Development Policies and Plans. The Case of Ghana's Relationship with the International Monetary Fund and the World Bank (Unpublished Doctoral Thesis. University of Sheffield, Sheffield).

Owusu, V. L. (2014). Institutional Texts and the Processes of Meaning Making. Toronto. International Journal of English Linguistics, 4(4), 1-12. http://dx.doi.org/10.5539/ijel.v4n4p1

Petticrew, M., \& Roberts, H. (2005). Systematic Reviews in the Social Sciences: A Practical Guide. Oxford. Blackwell.

Randolph, J. (2012). Environmental Land Use Planning and Management (2nd ed.). Washington. Island Press.

Victor, L. (2008). Systematic Reviewing. Social Research Update, 54, 1-4.

\section{Copyrights}

Copyright for this article is retained by the author(s), with first publication rights granted to the journal.

This is an open-access article distributed under the terms and conditions of the Creative Commons Attribution license (http://creativecommons.org/licenses/by/3.0/). 